\title{
CHEMICAL-LOOPING TECHNOLOGIES USING CIRCULATING FLUIDIZED BED SYSTEMS: STATUS OF DEVELOPMENT
}

\author{
Tobias Mattisson ${ }^{1 *}$, Martin Keller ${ }^{2}$, Carl Linderholm ${ }^{1}$, Patrick Moldenhauer ${ }^{1}$, Magnus \\ Ryden $^{1}$, Henrik Leion ${ }^{2}$, Anders Lyngfelt ${ }^{1}$
}

\author{
${ }^{1}$ Dept. of Energy and Environment and ${ }^{2}$ Dept. of Chemistry and Chemical Engineering, Chalmers \\ University of Technology, S-41296 Gothenburg, Sweden
}

*Email:tm@chalmers.se

\begin{abstract}
In chemical-looping combustion (CLC), an oxygen carrier provides lattice oxygen for complete combustion of a fuel for heat and power production. The reduced metal oxide is then oxidized in a separate reactor. The combustion products $\mathrm{CO}_{2}$ and $\mathrm{H}_{2} \mathrm{O}$ are obtained in pure form, without any nitrogen in the gas. As no gas separation work is needed, this could be a breakthrough technology for carbon capture (CCS). Normally, the fuel- and air-reactor are designed utilizing inter-connected fluidized beds. The same underlying reversible redox reactions of CLC can be used for other fuel conversion technologies. These include fluidized bed processes for gas, solid and liquid fuels for heat, power, syngas or hydrogen production. Some of these concepts were suggested as far back as the 1950's, while others have just recently been proposed. Chalmers University of Technology has been involved in CLC research for over 18 years, and this paper will provide a review of some recent developments with respect to CLC with gaseous, liquid and solid fuels. Further, the paper will provide an overview some related technologies where Chalmers is conducting research: i) Chemical-looping gasification (CLG), ii) Chemical-looping reforming (CLR) and iii) Chemical-looping tar reforming (CLTR). In these processes, a pure syngas/hydrogen can be produced effectively, which could be utilized for chemical or fuel production.
\end{abstract}

\section{INTRODUCTION}

In chemical-looping combustion (CLC) a reversible metal oxide is alternatingly reduced and oxidized using fuel and air respectively. The reactions can be described using (R1) and (R2),

$$
(2 n+m) \mathrm{Me}_{x} \mathrm{O}_{y}+\mathrm{C}_{n} \mathrm{H}_{2 m} \rightarrow(2 n+m) \mathrm{Me}_{x} \mathrm{O}_{y-1}+n \mathrm{CO}_{2}+m \mathrm{H}_{2} \mathrm{O}
$$

Here $M e_{x} O_{y}$ and $M e_{x} O_{y-1}$ are the fully oxidized and reduced forms of the oxygen carrier and $\mathrm{C}_{\mathrm{n}} \mathrm{H}_{2 \mathrm{~m}}$ is the fuel, and could be in gaseous, liquid or solid form. The reduced oxygen carrier is transported to the air reactor, where it is reoxidized with the combustion air according to:

$$
2 \mathrm{Me}_{x} \mathrm{O}_{y-1}+\mathrm{O}_{2} \rightarrow 2 \mathrm{Me}_{x} \mathrm{O}_{y}
$$

This sequence of reactions can be performed in two separate reactors, an air and a fuel reactor, with reaction (R1) occurring in the fuel reactor and reaction (R2) in the air reactor, see Fig. 1. The metal oxide is circulated between the reactors. Although the heat of combustion for CLC and normal combustion is the same, there are clearly some significant differences, which could have benefits with respect to emission control during the fuel conversion processes. The most obvious advantage is that $\mathrm{CO}_{2}$ is obtained in a separate stream from $\mathrm{N}_{2}$, meaning that $\mathrm{CO}_{2}$ can be obtained in pure form without gas separation. The increased awareness of the global warming problem, and the fact that CCS could be an important way of rapidly reducing emissions of greenhouse gases, has resulted in considerable research efforts around this break-through technology. A contributing factor to the popularity is the rather simple process and the fact that it can be implemented using conventional fluidized bed technology. (Lyngfelt et al., 2001) In addition to CLC, several novel fluidized bed conversion concepts utilizing metal oxide particles as fuel oxidants have been proposed in the last decade. The basis for these processes is the same: the use of highly reversible metal oxides which can transfer oxygen noncatalytically for full or partial oxidation of a fuel, normally utilizing fluidized bed technology. This paper will provide an overview of some of these novel fluidized bed combustion and gasification processes, starting with a discussion of some recent developments within CLC research.

\section{CHEMICAL-LOOPING COMBUSTION (CLC)}

Background - As is evident from Fig. 1, the gas stream from the fuel reactor contains a concentrated stream of $\mathrm{CO}_{2}$ and $\mathrm{H}_{2} \mathrm{O}$, while the nitrogen from the combustion air is obtained in the air reactor outlet. Possible 

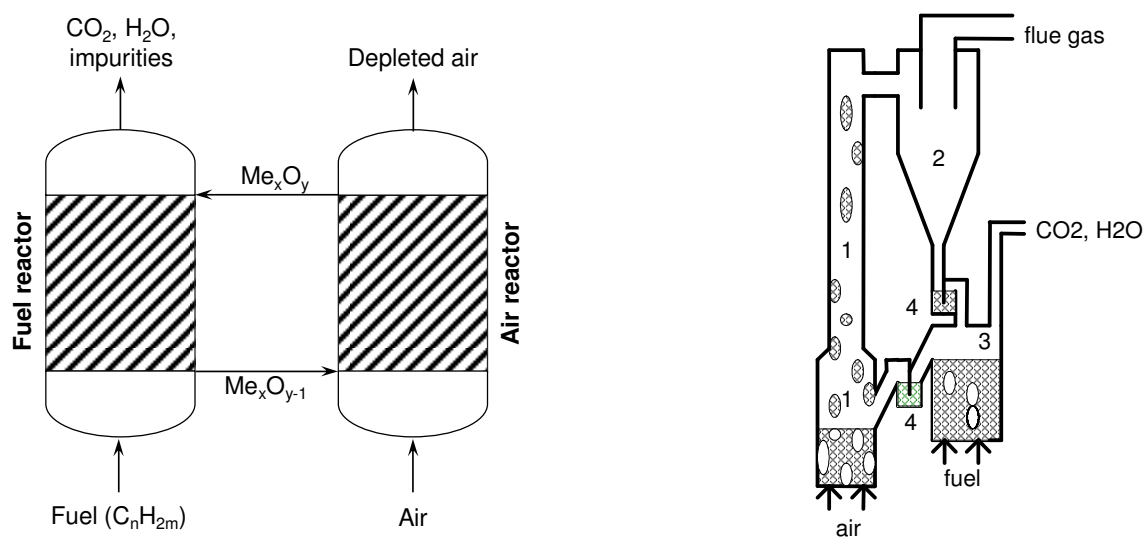

Fig. 1. Chemical-looping combustion process (left) designed with interconnected fluidized beds (right).

impurities from the fuel, such as $\mathrm{N}$-and S-species will likely be part of the concentrated stream from the fuel reactor, although impurities in the solid phase could be emitted with solid flows from the system. Already in the 1950's Lewis and Gilliland proposed a method for production of syngas or carbon dioxide from a carbonaceous fuel using iron and copper-based oxygen carrier. (Lewis et al., 1951) Although the aim of the proposed methodology had little to do with sustainable energy conversion, the concept is in principle the same as chemical-looping combustion, as coined by Ishida et al in 1987. (Ishida et al., 1987) There was only limited research in the 90's on the process, most of it performed by Ishida and co-workers, e.g. (Ishida et al., 1996) It was first in 1994 when the technology was proposed as a combustion option for efficient $\mathrm{CO}_{2}$ capture. (Ishida and Jin, 1994) At the start of the millennium the research around CLC accelerated, spurred by increased interest in carbon capture, where this emerging technology had a significant advantage with respect to efficiencies and costs in comparison to other technologies. The process was demonstrated for the first time in 2003 at Chalmers University of Technology, (Lyngfelt and Thunman, 2005) and since then a large number of materials have been investigated as oxygen carriers, and the technology demonstrated up to $3 \mathrm{MW}$ scale. (Abanades et al., 2015) The most common configuration for the process is that of coupled fluidized beds where the oxygen carrier is the bed material. Fig. 1 (right) shows a simple schematic of a reactor, as proposed by Lyngfelt et al. (Lyngfelt et al., 2001) The unit resembles that of a conventional circulating fluidized bed boiler (CFB) with the addition of a fuel reactor on the return side. Recently, Lyngfelt and Leckner presented a design and technoeconomic analysis of a 1000 MW CLC boiler based on two coupled circulating fluidized beds. (Lyngfelt and Leckner, 2015) The sum of the enthalpy from reaction (R1) and (R2) is the same as for conventional combustion, although the heat demand in each reactor is dependent on fuel and choice of oxygen carrier. Thus, the CLC process does not entail any direct cost or energy penalty for $\mathrm{CO}_{2}$ separation.

Fuels and oxygen carriers - The CLC process is highly fuel-flexible. The utilization of gaseous fuels is straightforward, and the gas is actually the fluidizing medium, e.g. (Kolbitsch et al., 2009) Liquid fuels could also be injected directly to the bed together with steam, although this likely depends on the viscosity and form of the fuel. (de Diego et al., 2016, Moldenhauer et al., 2014) For solid fuels, the fuel conversion process is a little bit different. The solid fuel is normally introduced directly into the fuel reactor together with the metal oxide particles. (Cuadrat et al., 2011) The fuel will here devolatilize to a gaseous fraction, i.e. volatiles, and solid char part. In parallel, the volatile part, composed mainly of $\mathrm{CO}, \mathrm{H}_{2}$ and $\mathrm{CH}_{4}$, reacts directly with the oxygen carrier particles according to overall reaction (R1).

The cornerstone of the CLC technology is finding oxygen carriers particles which are sufficiently reactive with fuel while at the same time having high resistance towards attrition over many redox cycles. Initial focus was on monometallic oxide systems based on the transition metals $\mathrm{Ni}, \mathrm{Fe}, \mathrm{Cu}$ and $\mathrm{Mn}$. These metals have oxide systems which enable a rapid bulk transfer of oxygen at conditions relevant for combustion. At this stage, it would be a monumental task to give a precise and all-encompassing overview of all materials tested in the laboratory, but there are a large number of review papers available, e.g. (Abanades et al., 2015, Luo et al., 2015) These papers give a broad view of the different materials which have been investigated for CLC and 

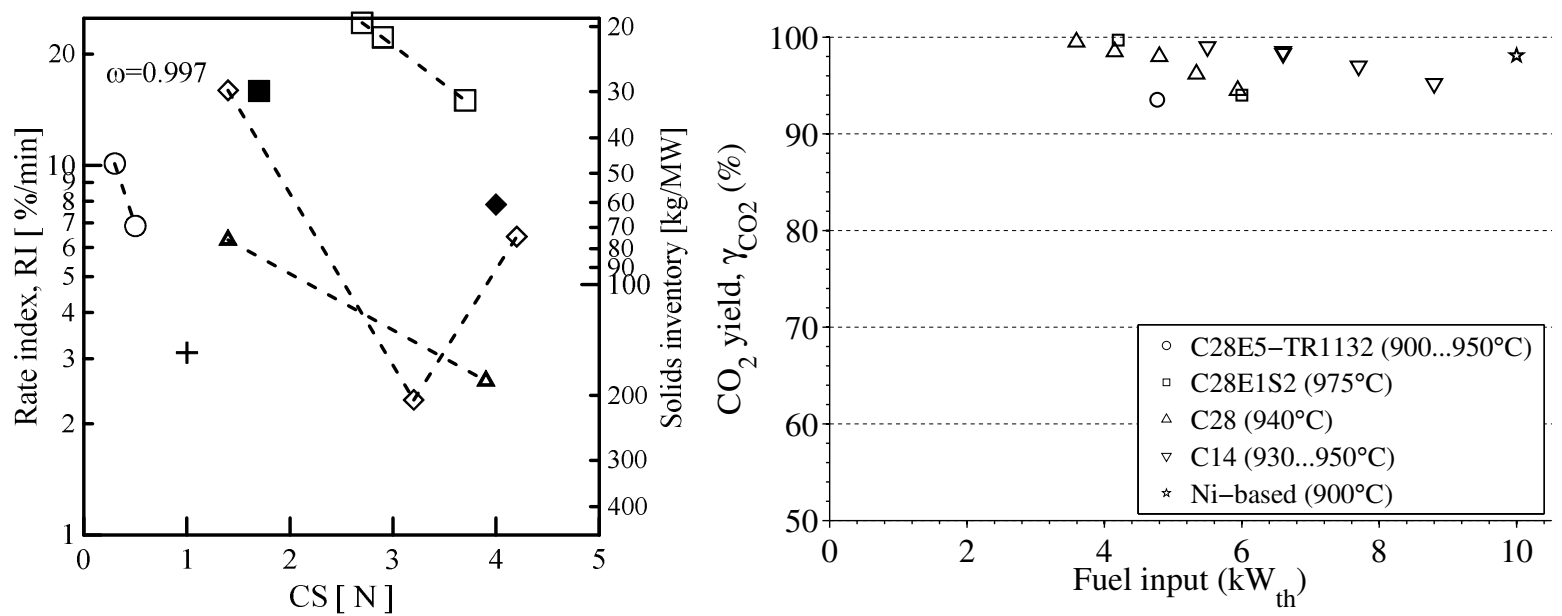

Fig. 2. Left figure shows the RI as a function of CS for several system combined manganese oxides, evaluated at $\omega=0.997$. Materials were studied with $\mathrm{CH}_{4}$ at $950^{\circ} \mathrm{C}:(\diamond) \mathrm{CaMn}_{0.9} \mathrm{Mg}_{0.1} \mathrm{O}_{3-\delta}(\mathrm{C} 14),(\square) \mathrm{CaMn}_{0.775} \mathrm{Mg}_{0.1} \mathrm{Ti}_{0.125} \mathrm{O}_{3-\delta}$, (C28), (O) Mn-Si, $(\triangle) \mathrm{MnMgO}_{\mathrm{X}},(+)\left(\mathrm{Mn}_{0.66} \mathrm{Fe}_{0.33}\right)_{2} \mathrm{SiO}_{3}$. Data are taken from (Jing et al., 2014, Jing et al., 2016, Mattisson et al., 2016). Right figure shows results from continuous experiments in Chalmers $10 \mathrm{~kW}$ circulating CLC unit for a series of promising materials based on optimized Ni- and Mn (composition C14, C28) oxygen carriers.

Data is taken from (Hallberg et al., 2016, Källén et al., 2013, Linderholm et al., 2009)

also overviews of the operational experience, which is now at least $9000 \mathrm{~h}$ worldwide. (Lyngfelt and Linderholm, 2016) According to Abanades et al. the research has taken the technology from a TRL (Technical Readiness Level) of 3 in 2005 to 6 today, i.e. from kW to MW scale. (Abanades et al., 2015)

Chemical-looping with oxygen uncoupling (CLOU) - A variant of CLC is the chemical-looping with oxygen uncoupling (CLOU) concept. (Mattisson et al., 2009) Here, the oxygen carrier particles release oxygen to the gas phase in the fuel reactor, i.e.

$$
2 \mathrm{Me}_{x} \mathrm{O}_{y} \rightarrow 2 \mathrm{Me}_{x} \mathrm{O}_{y-1}+\mathrm{O}_{2}
$$

The released oxygen can react directly with the fuel through normal combustion. CLOU particles need to have special thermodynamic and kinetic requirements in comparison to oxygen carriers used in normal CLC, more specifically, i) The metal oxide need to release gaseous oxygen and have a sufficient equilibrium partial pressure of oxygen at relevant combustion temperatures, ii) the oxide system needs to have an equilibrium partial pressure low enough for oxidation to be possible at the oxygen concentration level in the outlet of the air reactor, iii) The reactions in the fuel reactor should be overall exothermic, as this would result in a temperature increase, which will promote the release rate of gas-phase oxygen. There are several advantages with utilizing oxygen carriers with so-called uncoupling properties. The most significant advantages is likely related to enhanced solid fuel conversion, as the intermediate gasification steps in normal CLC are "replaced" by normal combustion.

For the CLOU process it is important to consider the important interplay between oxygen partial pressure of the metal oxide system, the heats of reaction and the temperature in the reactors. Although both $\mathrm{Mn}$ and Co have oxide systems which could be utilized in CLOU at certain temperatures and partial pressures of $\mathrm{O}_{2}, \mathrm{CuO}$ seems to be the only monometallic oxide with suitable thermodynamic and kinetic properties. (Adanez-Rubio et al., 2012, Ryden et al., 2014) Still, Cu-based materials are burdened with low melting temperatures, high cost and the fact that it is not possible to obtain natural materials with sufficient active content of $\mathrm{CuO}$ to be used in the chemical-looping process. Pure $\mathrm{Mn}_{2} \mathrm{O}_{3}$ could release $\mathrm{O}_{2}$ in the fuel reactor, but the kinetics seem to be slow at the lower temperatures which need to be employed. Recently, however, a number of articles have been published utilizing combined oxides as oxygen carriers for CLOU, e.g. (Azimi et al., 2013, Jing et al., 2012, Shulman et al., 2011 ). The common denominator for all of these investigated materials is that they contain manganese in the structure, but combined with $\mathrm{Ca}, \mathrm{Mg}, \mathrm{Fe}, \mathrm{Ni}$ and/or Si. Normally, these combined oxides have an equilibrium partial pressure of $\mathrm{O}_{2}$ which is somewhat higher than for pure $\mathrm{Mn}_{2} \mathrm{O}_{3}$, meaning that higher temperatures can be used in the combustion process, i.e. $850-1000^{\circ} \mathrm{C}$. Fig. 2 (left) shows the reactivity with methane, expressed as Rate index (RI), for a series of combined manganese oxides investigated by Jing. (Jing, 2015) The rate index is the normalized conversion rate expressed in percentage mass change per minute,

$$
\text { Rate index }(\mathrm{RI})=60 \cdot 100 \cdot(d \omega / d t)_{\text {norm }}
$$

The normalized rate of solid conversion of oxygen carrier is calculated from a pseudo-first order effective rate constant, $\mathrm{k}_{\mathrm{eff}}$, and a reference partial pressure of reactant gas, 

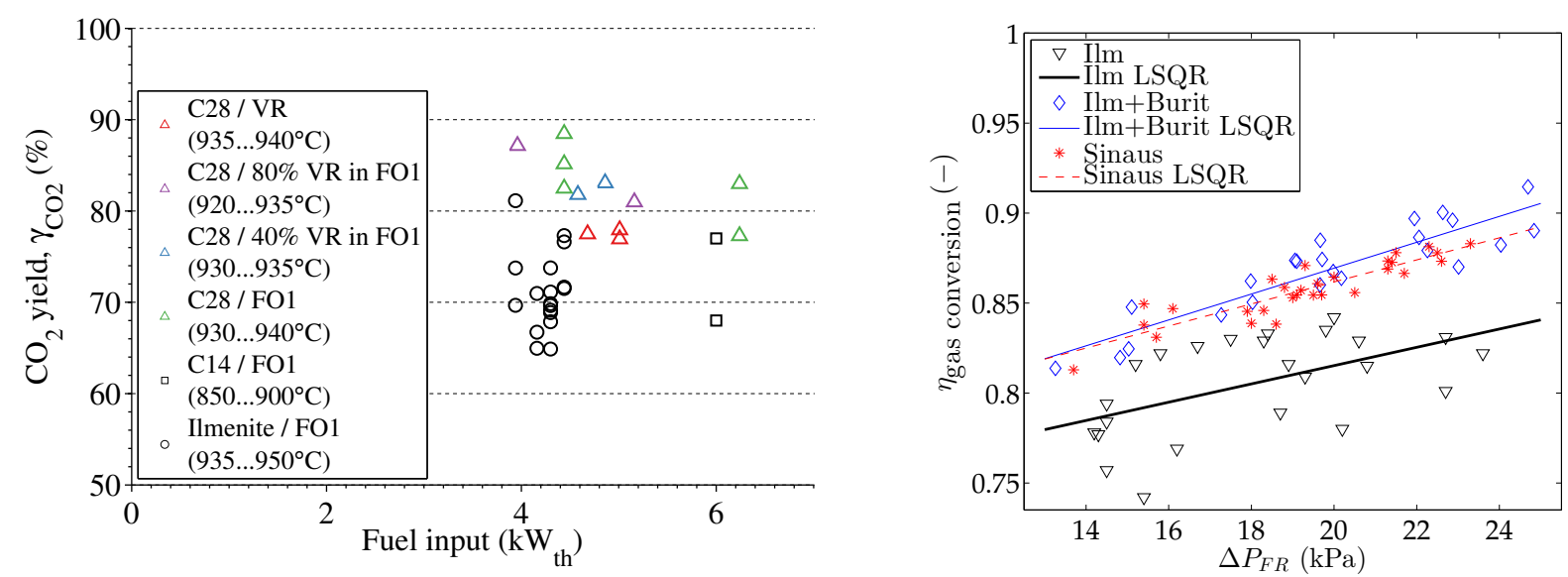

Fig. 3. Left figure shows results from tests with direct liquid fuel injection into Chalmers continuous circulating 10 kW pilot plant. (Moldenhauer et al., 2017, Moldenhauer et al., 2014) Here VR=Vacuum Residue and FO1=Fuel oil. Right figure shows the gas conversion as obtained in Chalmers $100 \mathrm{~kW}$ solid fuel pilot using bituminous coal and ilmenite, ilmenite + Mn-ore and only Mn-pre (Sinaus). Data is taken from (Linderholm et al., 2017, Linderholm et al., 2016, Markström et al., 2013a)

$$
(d \omega / d t)_{\text {norm }}=k_{\text {eff }}(\omega) p_{\text {ref }}
$$

Here, $p_{\text {ref }}$ is the reference partial pressure of $\mathrm{CH}_{4}$ which the bed of particles are exposed to in the fuel reactor and $\omega$ is the mass-based degree of conversion of the solid material. In Fig. 2, pref has been set to 0.15, corresponding to a mean partial pressure of methane which would be obtained at a higher degree of gas yield. The RI is a simple and transparent way of comparing reactivity of oxygen carriers, and the underlying assumptions can be found in Jing et al. (Jing et al., 2016) Further, the mass of bed material needed in the fuel reactor is proportional to the rate index, and this is also given in Fig. 2 for methane. The RI varied in a wide range, but there were several systems which displayed a combination of high reactivity and crushing strength, $\mathrm{CS}$, i.e. $>2 \mathrm{~N}$. One of the more interesting perovskite material based on $\mathrm{CaMnO}_{3-\delta}(\mathrm{C} 14, \mathrm{C} 28)$ has been developed in two recent European projects, INNOCUOUS and SUCCESS, e.g. (Mattisson et al., 2014, Mayer et al., 2015) Materials based on this composition has also been tested in Chalmers $10 \mathrm{~kW}$ reactor, see below.

Recent operational experience at Chalmers using gaseous, liquid and solid fuels - At Chalmers University of Technology, various continuous CLC units have been operated with gaseous, liquid and solid fuels during more than $3700 \mathrm{~h}$. The main portion of the investigations have been carried out as part of EU, RFCS or ERCfinanced projects related to development of the CLC technology. For gaseous fuels, such as natural or refinery gas, a series of EU-financed projects starting in 2001 (GRACE) have developed long-lasting oxygen carriers with high reactivity. Fig. 2 (right) shows some results of gas yield as a function of fuel power for various oxygen carriers developed in these projects using methane/natural gas, as obtained in a $10 \mathrm{~kW}$ circulating pilot plant, similar in design as the one shown in Fig. 1 (right). Here, the gas yield is defined as $\gamma_{\mathrm{CO} 2}=\mathrm{p}_{\mathrm{CO} 2} /\left(\mathrm{p}_{\mathrm{CO} 2}+\mathrm{p}_{\mathrm{CO}}+\mathrm{p}_{\mathrm{CH} 4}\right)$, where $\mathrm{p}_{\mathrm{i}}$ is the outlet partial pressure of component $\mathrm{i}$. The unit is characterized by a high velocity air reactor/riser and a low velocity bubbling fuel reactor. Initially, the focus was on Ni-based materials, which had significant advantages with respect to methane conversion, compared to other metal oxides. Due to cost and issues with toxicity of Ni, later projects (INNOCUOUS, SUCCESS) have had a certain focus on Mn-based materials, especially $\mathrm{CaMn}_{0.9} \mathrm{Mg}_{0.1} \mathrm{O}_{3-\delta},(\mathrm{C} 14)$ and $\mathrm{CaMn}_{0.775} \mathrm{Mg}_{0.1} \mathrm{Ti}_{0.125} \mathrm{O}_{3-\delta}$, (C28). Although conditions are somewhat different for the series of materials shown in Fig. 2 (right), evidently almost full gas yield can be obtained with optimized materials of both $\mathrm{Ni}$ - and $\mathrm{Mn}$. The specific oxygen carrier inventory in the fuel reactor for the tests in Fig. 2 varied in the range $480-800 \mathrm{~kg} / \mathrm{MW}_{\text {th }}$, with the lowest inventories used for $\mathrm{Ni}$. The high gas yields seen with combined Mn-oxides can likely be attributed to the CLOU effect seen with these type of perovskites.

For liquid fuels, Chalmers was the first research group to directly inject liquid fuels into the fuel reactor, and Fig 3 (left) shows some results using fuel oil and heavy vacuum residue as fuel, also operated using a reactor configuration close to the one in Fig. 1. (Moldenhauer et al., 2017, Moldenhauer et al., 2014) Here, the benchmark oxygen carriers ilmenite and C28 were used. Also high gas yields could be obtained using heavy liquid hydrocarbon fuels, although high specific solids inventories were employed in these investigations, up to $2000 \mathrm{~kg} / \mathrm{MW}_{\text {th }}$ in the fuel reactor.

In the last decade Chalmers has also performed research using solid fuels, such as coal, petroleum coke and biomass. (Leion et al., 2007, Linderholm and Schmitz, 2016, Markström et al., 2012) With respect to 
continuous operation, two pilot units of nominal power 10 and $100 \mathrm{kWth}$ have been employed, whereof the latter is designed using two coupled circulating fluidized beds. (Markström et al., 2013b) Figure 3 (right) shows gas conversion versus the solids inventory, expressed as pressure drop in the fuel reactor for several oxygen carrier materials as obtained in this pilot plant. (Linderholm et al., 2017, Linderholm et al., 2016, Markström et al., 2013a) The gas conversion was calculated as $\eta_{\mathrm{gas}}=\left(1-\Omega_{\mathrm{OD}}\right)$, where $\Omega_{\mathrm{OD}}$ is the oxygen demand. (Markström et al., 2013a) The oxygen carriers used were (i) ilmenite ("Ilm"), (ii) a mixture of ilmenite and Buritirama manganese ore ("Burit"), and (iii) new results with a sintered manganese ore, Sinaus. Bituminous coal was used as fuel in all experiments shown here. The temperature varied between $935-980{ }^{\circ} \mathrm{C}$ and the fuel power was $80 \mathrm{~kW}$ for ilmenite, $50-117 \mathrm{~kW}$ for the mixture of ilmenite and Buritirama manganese ore and $57-95 \mathrm{~kW}$ for Sinaus. The specific solids inventory in the fuel reactor varied between 360-750 $\mathrm{kg} / \mathrm{MW}_{\text {th }}$. Clearly improved gas conversion was obtained for the cases utilizing manganese ores in comparison to the bench-mark oxygen carrier ilmenite. Most recent results indicate that also losses of char can be kept low, both char elutriated with gas flow and char in the flow to the air reactor. (Lyngfelt et al., 2016)

\section{CHEMICAL LOOPING REFORMING (CLR) AND GASIFICATION (CLG)}

Chemical-looping technologies can also be used for syngas production, a valuable feedstock for chemicals or hydrogen. Below, three chemical-looping concepts for syngas production will be discussed using natural gas/refinery gas or solid fuels (such as biomass or waste) as feedstocks.

Chemical-looping reforming (CLR) - The conventional way of generating a syngas from a hydrocarbon gaseous fuel, such as natural gas, is through steam reforming. Here, heat for the highly endothermic reactions is generated in gas-fired furnaces operating at high temperatures. Heat is transferred to the reformer tubes mainly by radiation. There are numerous chemical-looping configurations for converting a gaseous fuel, such as natural gas or refinery gas, to syngas or hydrogen. (Fan, 2010) Two different concepts will be discussed briefly in this paper: $i$ ) autothermal CLR (ACLR) and $i$ ) CLC with steam reforming (CLC-SR). ACLR is very similar to normal CLC, as seen in Fig. 1, but with the difference that mainly $\mathrm{CO}$ and $\mathrm{H}_{2}$ are obtained in the exit from the fuel reactor. The hydrocarbon fuel is mainly converted by the partial oxidation reactions, where the oxygen carrier provides the oxygen. The difference with respect to CLC is that only enough oxygen is provided for oxidation to $\mathrm{CO}$ and $\mathrm{H}_{2}$. In practice this can be achieved by operating the reactor system at lower air-ratios compared to normal combustion. To establish an autothermal process, some $\mathrm{H}_{2} \mathrm{O}$ and $\mathrm{CO}_{2}$ may also need to be generated in the fuel reactor, and may also be formed through the water-gas shift reaction. The main advantage with such a concept is that no costly air separation unit is needed in order to obtain a concentrated syngas stream. Further, a syngas with a relatively high $\mathrm{CO} / \mathrm{H}_{2}$ ratio can be obtained, which may be advantageous for production of certain chemicals or fuels. If a decarbonized fuel is desired, pure $\mathrm{H}_{2}$ can be obtained after treating the outlet gas stream from the fuel reactor in water gas shift reactors and finally separating the $\mathrm{CO}_{2}$ from the $\mathrm{H}_{2}$ stream using an absorbent. (Ryden, 2008)

Zafar et al., showed that of the traditional transition metals $\mathrm{Fe}, \mathrm{Mn}, \mathrm{Ni}$ and $\mathrm{Cu}$, only the system NiO-Ni has a high methane conversion and accompanying high selectivity towards $\mathrm{CO}$ and $\mathrm{H}_{2}$. (Zafar et al., 2005) Ni-based oxygen carriers are also by far the most studied materials for ACLR. In most investigations, $\mathrm{NiO}$ with an inert support have been tested, (Johansson et al., 2008, Ortiz et al., 2011a, Ryden et al., 2006) but there are also several investigtions employing mixed oxides with nickel as part of the structure. ACLR has been demonstrated at various scale, e.g. (De Diego et al., 2009, Pröll et al., 2010, Ryden et al., 2006)

Steam reforming combined with CLC (SR-CLC) - The second configuration for hydrogen production from natural gas is the SR-CLC concept, as proposed by Ryden and Lyngfelt.(Rydén and Lyngfelt, 2006) Here a conventional CLC reactor system is used as the heat source for the conventional steam reforming reaction. The conventional reforming tubes are placed inside a fluidized bed heat exchanger (FBHE). The steam reforming reaction which takes place in the conventional reforming tubes, produces a syngas of mainly $\mathrm{CO}$ and $\mathrm{H}_{2}$, but also small amounts of $\mathrm{CH}_{4}, \mathrm{CO}_{2}$ and other impurities. The syngas is then partially shifted in a WGS before the hydrogen is separated in a pressure-swing adsorption unit (PSA). The tailgas from the PSA contains a number of burnable components, such as $\mathrm{H}_{2}, \mathrm{CO}$ and $\mathrm{CH}_{4}$. This gas is used as the fuel for the CLC. The concept provides several advantages. Most importantly, high efficiencies can be obtained using a combination of conventional reforming tubes and an atmospheric CLC reactor, i.e. there is no need for complex pressurized fluidized beds. The main reason for the high efficiency is a shift in heat-transfer characteristics. In contrast to normal SMR, in SR-CLC, the main heat transfer mechanism to the reformer tubes is by 
a) $\mathrm{Fe}, \mathrm{Sr}$-doped lanthanum zirconate

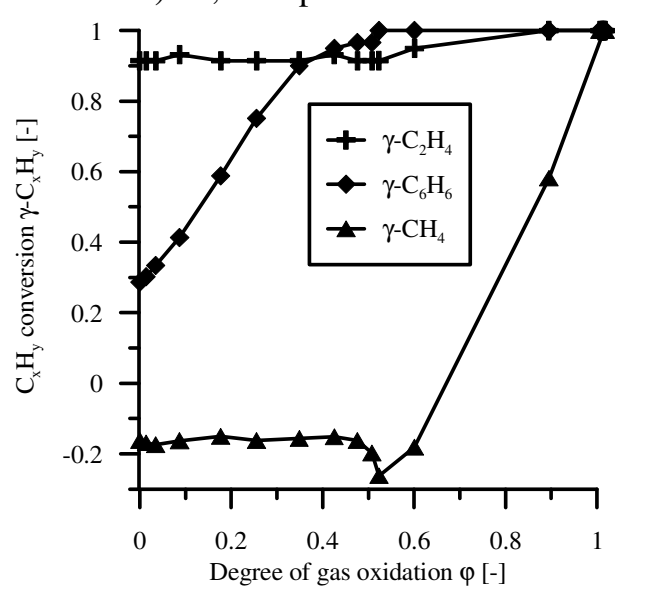

b) $\mathrm{Cu}$ on $\gamma-\mathrm{Al}_{2} \mathrm{O}_{3}$ support (PURALOX)

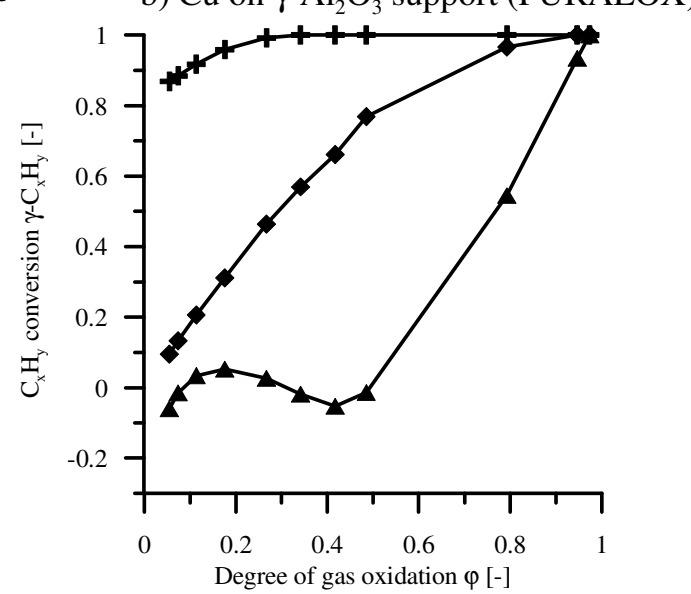

Fig. 4. Hydrocarbon conversion in CLTR in synthetic gasification gas as a function of degree of gas oxidation at $\mathrm{T}=$ $800{ }^{\circ} \mathrm{C}$ over (left) $\mathrm{Fe}, \mathrm{Sr}$-doped lanthanum zirconates and (right) $\mathrm{Cu}$-based material investigated at Chalmers.

convection from the hot particles. As this heat transfer mechanism is more efficient than gas radiation, the heat transfer can be conducted at lower temperatures. This means that a larger fraction of the fuel heating value can be obtained as $\mathrm{H}_{2}$, resulting in a higher cold-gas efficiency compared to normal SMR. With respect to development of oxygen carrier particles for this concept, the criteria which are valid for normal CLC would apply to SR-CLC. As the tailgas contains significant amounts of $\mathrm{CO}$ and $\mathrm{H}_{2}$, iron or manganese oxides may be highly suitable, especially when considering their low cost and availability as natural materials. Most work around this novel concept has been conducted by Adanez et al. (Ortiz et al., 2011b, Pans et al., 2013)

Chemical-looping gasification (CLG) - A syngas can also be produced from solid fuels using chemical looping gasification (CLG). Here, a solid fuel, such as coal or biomass, is gasified in the presence of a metal oxide bed material that provides lattice oxygen to the gasification process. This is achieved by recirculating the bed material between a fuel reactor, in which the fuel together with a gasification agent $\left(\mathrm{H}_{2} \mathrm{O} / \mathrm{CO}_{2}\right)$ is fed, and an air reactor in which the bed material is regenerated in air, in a similar fashion as in the CLC process. In contrast to the CLC process, the objective of CLG is not to fully combust the fuel to generate heat, but to only partially oxidize it in order to obtain a $\mathrm{N}_{2}$-free product gas with high heating value that contains predominantly $\mathrm{H}_{2}, \mathrm{CO}, \mathrm{CO}_{2}$ and $\mathrm{H}_{2} \mathrm{O}$.

The CLG process is in many aspects similar to the Dual Fluidized Bed (DFB) gasification process. In the DFB process, the bed material does not transport any oxygen between the two reactors. Instead, the heat required for the endothermic steam gasification is generated by combustion of the char transported with the bed material from the fuel reactor to the air reactor. This generates a flue gas stream with depleted air and $\mathrm{CO}_{2}$ from the air reactor. In contrast, the CLG process aims at transporting lattice oxygen via the oxygen carrier particles. The sensible heat demand is provided by the exothermic oxidation reaction in the air reactor. In order to maintain a high cold gas efficiency of the process, CLG requires complete or a high degree of char conversion in the fuel reactor. The amount of oxygen transported from the air reactor to the fuel reactor needs to be carefully moderated in order to avoid full oxidation of too much of the product gas and thus a reduced heating value of the synthesis gas. This can be achieved, for example, by mixing oxygen-carrying bed material with bed material that does not transport oxygen, or by limiting the circulation rate of the bed material. (Larsson et al., 2014)

Recently, CLG of solid fuels has been investigated by several research groups with a variety of different oxygen carriers, e.g. (Aghabararnejad et al., 2014, Guo et al., 2014) The CLG of biomass (rice husk) in a continuous setup with two interconnected fluidized beds using natural hematite mixed with sand as an oxygen carrier and steam as a gasification agent in the fuel reactor was investigated, and rather high syngas yields were observed. (Ge et al., 2016a, Ge et al., 2016b) At Chalmers, Larsson et al. investigated the use of 12 wt-\% natural ilmenite ore $\left(\mathrm{FeTiO}_{3}\right)$ mixed with silica sand in a 2-4 MW DFB gasifier. (Larsson et al., 2014) In comparison to a base case using only sand, they observed a decrease of the heating value and the cold gas efficiency of the gasifier due to the oxygen transport, and a decrease in total tar yield. However, the fraction of heavy tars increased. Recently, the use of red mud, a waste product of bauxite refining, was investigated for its use in CLG, and it was found that its Fe content contributed lattice oxygen to the gasification process and that the water gas shift reaction and the char gasification were catalyzed by the material to some extent. (Chen et al., 2017) 
In summary, research undertaken thus far indicates that the CLG process presents a promising technology for solid fuel gasification, in particular for biogenic fuels. In comparison with the related DFB process, the main projected advantages are the higher carbon utilization and the avoidance of emissions from the air reactor. The possibility to partially oxidize tars, either catalytically or non-catalytically may be an additional advantage.

\section{CHEMICAL-LOOPING TAR REFORMING (CLTR)}

Raw gasification gas, in addition to its main constituents $\mathrm{CO}, \mathrm{CO}_{2}, \mathrm{H}_{2}$ and $\mathrm{H}_{2} \mathrm{O}$, contains substantial amounts of hydrocarbons and other contaminants and impurities such as sulphur compounds and ammonia. Apart from non-condensable hydrocarbons such as $\mathrm{CH}_{4}, \mathrm{C}_{2}-\mathrm{C}_{5}$ compounds and monoaromatics, the raw synthesis gas also contains heavier, condensable hydrocarbons commonly referred to as tars. (Torres et al., 2007) Tars may condense in downstream equipment which may lead to fouling and blocking. (Li and Suzuki, 2009)

The application of the Chemical Looping principle has been proposed as a way of converting tars and other hydrocarbons into valuable syngas compounds that can be utilized in downstream synthesis processes. (Lind et al., 2011) In this process, termed CLTR, a catalytically active bed material is circulated between a reformer, in which the bed material is in contact with the raw synthesis gas, and a regenerator, in which the bed material is regenerated with air. In the reformer the hydrocarbon compounds are catalytically reformed with steam, cracked or partially oxidized by the lattice oxygen of the metal oxide oxygen carrier. Catalytically active bed materials should be employed that preferentially convert hydrocarbons by steam reforming while limiting the oxidation of valuable syngas compounds $\mathrm{H}_{2}$ and $\mathrm{CO}$. The deposition of coke and sulfides may deactivate the bed material. The deactivated bed material is then recirculated back to the regenerator, where it is reoxidized and coke deposits are burnt off with air. While some degree of oxidation of the raw syngas by the lattice oxygen in CLTR is desirable in order to provide heat for the endothermic steam reforming, care must be taken to limit this oxidation so that a high heating value of the syngas is retained. This can be achieved by either controlling the circulation rate of the bed material, tailoring the oxygen carrying capacity of the bed material, or by providing a limited amount of oxygen to the regenerator.

The CLTR process has been investigated in a continuous unit using raw gasification gas from the Chalmers 2$4 \mathrm{MW}_{\text {th }}$ DFB gasifier using an ilmenite $\left(\mathrm{FeTiO}_{3}\right)$ natural ore, (Lind et al., 2013, Lind et al., 2011) a Manganese natural ore, (Marinkovic et al., 2015a) $\mathrm{Mn}_{3} \mathrm{O}_{4}$ supported on $\mathrm{ZrO}_{2}$ (Lind et al., 2012) and $\mathrm{NiO}$ supported on $\alpha$ $\mathrm{Al}_{2} \mathrm{O}_{3}$ (Berguerand et al., 2012, Lind et al., 2013) as bed materials. The use of ilmenite resulted in a significant reduction of the amount of $\mathrm{C}_{2}$ hydrocarbons, in a reduction in the total amount of tars, but in an increase in aromatic compounds in the gas. (Lind et al., 2013) Similarly, with the $\mathrm{Mn}_{3} \mathrm{O}_{4} / \mathrm{ZrO}_{2}$ bed material a reduction of the gravimetric tar content, mainly due to the conversion branched aromatic and phenolic compounds, but an increase of benzene and naphthalene concentration was observed. (Lind et al., 2012) With Mn ore, unbranched aromatics such as benzene and naphthalene were not converted, while $\mathrm{C}_{2}$ and $\mathrm{C}_{3}$ hydrocarbons were converted efficiently, however at a significantly increased gas residence time in the reformer in comparison with earlier experiments. (Marinkovic et al., 2015b) Of the investigated materials, only the $\mathrm{Ni}$ catalyst was able to convert tars, $\mathrm{C}_{2}$ hydrocarbons, aromatic compounds and some $\mathrm{CH}_{4}$. However, concerns over cost and toxicity of $\mathrm{Ni}$-, Co or precious metal containing materials resulted in the search for alternative bed materials. In a screening study, $\mathrm{Cu}$-based bed materials and Fe-containing mixed oxides such as perovskites and pyrochlores were identified as promising bed materials. (Keller et al., 2014) The Cu-containing materials exhibited very high degrees of $\mathrm{C}_{2}$ hydrocarbon conversion, but did not reform monoaromatic compounds, (Keller et al., 2016a) rendering them valuable when BTX compounds are separated from the synthesis gas as byproducts. (van der Drift, 2013) With Fe,Sr-doped lanthanum zirconates, high degrees of $\mathrm{C}_{2}$ hydrocarbon and benzene conversion were achieved, while retaining $\mathrm{CH}_{4}$ in the synthesis gas. A benzene conversion of up to $60 \%$ and an ethylene conversion of about $90 \%$ could be achieved at a temperature of $850^{\circ} \mathrm{C}$ and at a rather high Gas Hourly Space Velocity (GHSV) of $6800 \mathrm{~h}^{-1}$. (Keller et al., 2016b) With both the $\mathrm{Cu}$-based materials and the $\mathrm{Fe}, \mathrm{Sr}$-doped lanthanum zirconates the conversion of hydrocarbons could be further improved by partially oxidizing the product gas with lattice oxygen taken up in the regenerator. This is illustrated in Fig. 4. For both materials, the order of preferential oxidation by the lattice oxygen was $\mathrm{C}_{2} \mathrm{H}_{4}>$ $\mathrm{C}_{6} \mathrm{H}_{6}>\mathrm{CH}_{4}$. A brief comparison of the properties of the $\mathrm{Cu}$-based and $\mathrm{Fe}, \mathrm{Sr}$-doped $\mathrm{La}_{2} \mathrm{Zr}_{2} \mathrm{O}_{7}$ bed material is shown in Table 1.

The CLTR process is still in an early stage of development and thus its commercial feasibility is difficult to judge. However, its interesting set of potential advantages over other tar removal technologies provides a strong incentive for further research and development. 
Table 1. Comparison of properties of interest for CLR of two promising bed materials

\begin{tabular}{|c|c|c|c|c|c|}
\hline & $\begin{array}{c}\text { Reactivity } \\
\text { towards } \mathbf{C}_{2} \mathbf{H}_{4}\end{array}$ & $\begin{array}{c}\text { Reactivity } \\
\text { towards } \mathbf{C}_{6} \mathbf{H}_{6}\end{array}$ & $\begin{array}{c}\text { Oxygen transport } \\
\text { capacity }\end{array}$ & $\begin{array}{c}\text { Coke } \\
\text { formation }\end{array}$ & Potential application \\
\hline $\mathrm{Cu} / \mathrm{Al}_{2} \mathrm{O}_{3}$ & high & low & high & high & $\begin{array}{c}\text { BTX by-product } \\
\text { production }\end{array}$ \\
\hline $\begin{array}{c}\mathrm{Fe}, \mathrm{Sr}_{-} \text {doped } \\
\mathrm{La}_{2} \mathrm{Zr}_{2} \mathrm{O}_{7}\end{array}$ & high & high & low & low & $\begin{array}{c}\text { Total } \mathrm{C}_{\mathrm{x}} \mathrm{H}_{\mathrm{y}} \text { conversion, } \\
\text { retain } \mathrm{CH}_{4}\end{array}$ \\
\hline
\end{tabular}

\section{OUTLOOK}

The conflicting need for rapid and drastic reductions in carbon dioxide emissions but no globally binding climate agreement in place translates into a serious problem for humanity. Without the necessary economic incentives in place, it is unlikely that industry will make the necessary investments in technologies which can enable a rapid decrease in $\mathrm{CO}_{2}$ emissions, most importantly carbon capture and storage (CCS). However, it is important to consider that all of the discussed processes in this paper have significant similarities with circulating fluidized bed boilers (CFBB), a well-known and commercially available technology for combustion of solid fuels. Thus in many cases it is believed that the extra cost involved for modifying or retrofitting a CFB boiler may be limited and associated with low risk. The dual-bed nature of the proposed conversion processes also presents opportunities with respect to limiting or eliminating emissions of trace gases and high temperature corrosion, which could also spark interest and promoted deployment and scale-up. Below follows a short discussions concerning the outlook for three promising chemical-looping concepts, whereof two have been discussed in the paper:

- CLC/CLOU: In an analysis of the additional costs associated with a CLC, in comparison to a large CFB burning coal, Lyngfelt and Leckner found that the cost difference between a conventional CFB boiler and a CLC boiler was mainly related to the insulated walls of fuel reactor and associated peripherals, corresponding to an added cost of less than $1 € /$ ton $\mathrm{CO}_{2}$. Total estimated costs were higher, around $20 € /$ ton $\mathrm{CO}_{2}$, which is still very low in comparison to competing technologies (Lyngfelt and Leckner, 2015). As a large part of this cost is associated with $\mathrm{CO}_{2}$ compression and oxy-polishing, it is expected that a flexible CFB-CLC could be erected at low additional cost which could be operated with or without carbon capture depending upon market conditions. In comparison to a normal CFB, the fuel reactor cross-sectional area and corresponding flow is only about $1 / 4$ of the entire crosssectional area and flow of the boiler. (Lyngfelt and Leckner, 2015) It is expected that the fuel and associated impurities are converted mainly in the fuel reactor, and thus concentrated in the small volumetric flow from this reactor, which should be positive with respect to downstream clean-up. More importantly, the air reactor will be largely free from gaseous and solid impurities, and as most of the heat of combustion will be extracted here, it opens up the possibility for enhanced steam data when burning fuels such as biomass or waste, with high concentrations of alkali and chlorine, known precursors for high-temperature corrosion on heat-transfer surfaces during normal combustion, e.g. (Glarborg and Marshall, 2005, Kassman, 2012, van Lith et al., 2006)

- Oxygen carrier aided combustion (OCAC): This concept, proposed by Thunman et al. (Thunman et al., 2013) uses oxygen carriers instead of sand in a conventional fluidized bed boiler opens up. It has been shown that the underlying redox reactions of the oxygen carrier results in a more even oxygen potential in the furnace, with positive consequences with respect to emissions of $\mathrm{CO}$ and NO. This is certainly a highly interesting area of research, which is applicable immediately. (Zhao et al., 2014) In fact, the process is being exploited by the energy provider E.ON, which has already demonstrated the process in a $75 \mathrm{MW}$ fluidized bed boiler burning waste. (Andersson et al., 2016) With respect to the low costs predicted for CFB-CLC above, the advantages reported for OCAC certainly opens up the possibity for low cost and efficient " $\mathrm{CO}_{2}$-ready" fluidized bed combustion units.

- Hydrogen production: The SR-CLC discussed in this paper has the possibility for high hydrogen yields with carbon capture. (Ryden and Lyngfelt, 2004) Stenberg et al. also opened up the possibility for combining OCAC with steam reforming, or SR-OCAC. (Stenberg et al., 2016) As with the combustion processes discussed above, this opens up the possibility for yet another transition technology which could be of interest in a market scenario where there is little or no economic incentive for CCS. 


\section{CONCLUSIONS}

This paper has provided an overview of chemical-looping technologies, focusing on research conducted at Chalmers. Chemical-looping combustion of gaseous, liquid and solid fuels has been demonstrated successfully using optimized and low-cost oxygen carriers. Some other promising fluidized chemical-looping technologies utilizing metal oxide particles have been discussed: i) Oxygen carrier aided combustion (OCAC), ii) Chemical-looping gasification (CLG), iii) Chemical-looping reforming (CLR) and iv) Chemical-looping tar reforming (CLTR). Although the main driving force for utilization of CLC is for combustion with CCS, these processes may be applicable and efficient methods for combustion or syngas/hydrogen production without the use of carbon capture.

\section{ACKNOWLEDGEMENT}

This work was financed by the European Uniong as part of the FP7 project SUCCESS (agreement no ${ }^{\circ} 605871$ ), and the ERC-ADG project "NoCO2". Additional financial support from the Chalmers Area of Advance profile "Energy in a Circular Economy (ECE)" is gratefully acknowledged.. This paper is dedicated to the memory of our friend and colleague Dr. Dongmei Zhao, who passed away $18^{\text {th }}$ of December, 2016. Her kindness and enthusiasm will always be remembered.

\section{REFERENCES}

ABANADES, J., ARIAS, B., LYNGFELT, A., MATTISSON, T., WILEY, D., LI, H., HO, M., MANGANO, E. \& BRANDANI, S. 2015. Emerging CO2 capture systems. International Journal of Greenhouse Gas Control, 40, 126-166.

ADANEZ-RUBIO, I., ABAD, A., GAYAN, P., DE DIEGO, L., GARCIA-LABIANO, F. \& ADANEZ, J. 2012. Identification of operational regions in the chemical-looping with oxygen uncoupling (CLOU) process with a Cu-based oxygen carrier. Fuel, 102, 634-645.

AGHABARARNEJAD, M., PATIENCE, G. S. \& CHAOUKI, J. 2014. TGA and Kinetic Modelling of Co, $\mathrm{Mn}$ and $\mathrm{Cu}$ Oxides for Chemical Looping Gasification (Clg). Canadian Journal of Chemical Engineering, 92, 1903-1910.

ANDERSSON, B.-A., LIND, F., CONCORAN, A. \& THUNMAN, H. 2016. 4000 Hours of Operation with Oxygen-Carriers in Industrial Relevant Scale (75 MWth). 4th International conference on Chemical Looping. Nanjing, China.

AZIMI, G., RYDEN, M., LEION, H., MATTISSON, T. \& LYNGFELT, A. 2013. (MnyFe1-y)Ox combined oxides as oxygen carrier for chemical-looping with oxygen uncoupling (CLOU). AIChE Journal, 59, $582-588$.

BERGUERAND, N., LIND, F., ISRAELSSON, M., SEEMANN, M., BIOLLAZ, S. \& THUNMAN, H. 2012. Use of Nickel Oxide as a Catalyst for Tar Elimination in a Chemical-Looping Reforming Reactor Operated with Biomass Producer Gas. Industrial \& Engineering Chemistry Research, 51, 1661016616.

CHEN, L., YANG, L., LIU, F., NIKOLIC, H., FAN, Z. \& LIU, K. 2017. Evaluation of Multi-Functional IronBased Carrier from Bauxite Residual for H2-Rich Syngas Production via Chemical-Looping Gasification. Fuel Process. Technol, 156, 185-194.

CUADRAT, A., ABAD, A., GARCIA-LABIANO, F., GAYAN, P., DE DIEGO, L. \& ADANEZ, J. 2011. The use of ilmenite as oxygen carrier in a 500Wth chemical-looping coal combustion unit. Int. J. Greenhouse Gas Control, 5, 1630-1642.

DE DIEGO, L., ORTIZ, M., GARCIA-LABIANO, F., ADANEZ, J., ABAD, A. \& GAYAN, P. 2009. Hydrogen production by chemical-looping reforming in a circulating fluidized bed reactor using $\mathrm{Ni}$ based oxygen carriers. J. of Power Sources, 192, 27-34.

DE DIEGO, L., SERRANO, A., GARCÍA-LABIANO, F., GARCÍA-DÍEZ, E., ABAD, A., GAYÁN, P. \& ADÁNEZ, J. 2016. Bioethanol combustion with CO2 capture in a 1kWth Chemical Looping Combustion prototype: Suitability of the oxygen carrier Chemical Engineering Journal 283, 14051413.

FAN, L. 2010. Chemical-looping systems for fossil energy conversions, Hoboken, NJ, John Wiley and Sons, Inc.

GE, H. J., GUO, W. J., SHEN, L. H., SONG, T. \& XIAO, J. 2016a. Biomass gasification using chemical looping in a $25 \mathrm{~kW}$ th reactor with natural hematite as oxygen carrier. Chemical Engineering Journal, 286, 174-183.

GE, H. J., GUO, W. J., SHEN, L. H., SONG, T. \& XIAO, J. 2016b. Experimental investigation on biomass gasification using chemical looping in a batch reactor and a continuous dual reactor. Chemical Engineering Journal, 286, 689-700. 
GLARBORG, P. \& MARSHALL, P. 2005. Mechanism and modeling of the formation of gaseous alkali sulfates. Combustion and Flame, 141, 22-39.

GUO, Q. J., CHENG, Y., LIU, Y. Z., JIA, W. H. \& RYU, H. J. 2014. Coal Chemical Looping Gasification for Syngas Generation Using an Iron-Based Oxygen Carrier. Industrial \& Engineering Chemistry Research, 53, 78-86.

HALLBERG, P., HANNING, M., RYDEN, M., MATTISSON, T. \& LYNGFELT, A. 2016. Investigation of a calcium manganite as oxygen carrier during $99 \mathrm{~h}$ of operation of chemical-looping combustion in a $10 \mathrm{~kW}$ th reactor unit. Int. J. Greenhouse Gas Control, 53, 222-229.

ISHIDA, M. \& JIN, H. 1994. A novel combustor based on chemical-looping reactions and its reaction kinetics. Journal of Chemical Engineering of Japan, 27, 296-301.

ISHIDA, M., JIN, H. \& OKAMOTO, T. 1996. A fundamental study of a new kind of medium material for chemical-looping combustion. Energy \& Fuels, 10, 958-963.

ISHIDA, M., ZHENG, D. \& AKEHATA, T. 1987. Evaluation of a chemical-looping-combustion powergeneration system by graphic exergy analysis. Energy - the International Journal, 12, 147-154.

JING, D. 2015. Innovative oxygen carriers for chemical-looping combustion. Ph.D. Doctoral thesis, Chalmers University of Technology.

JING, D., ARJMAND, M., MATTISSON, T., RYDÉN, M., SNIJKERS, F., LEION, H. \& LYNGFELT, A. 2014. Examination of oxygen uncoupling behaviour and reactivity towards methane for manganese silicate oxygen carriers in chemical-looping combustion International Journal of Greenhouse Gas Control 29, 70-81.

JING, D., HERMANS, E., LEION, H., RYDÉN, M., MATTISSON, T., VAN NOYEN, J. \& LYNGFELT, A. 2012. Manganese-silica combined oxides as oxygen carrier for chemical-looping combustion $2 n d$ International conference on chemical looping. Darmstadt, Germany.

JING, D., JACOBS, M., HALLBERG, P., MATTISSON, T. \& LYNGFELT, A. 2016. Development of $\mathrm{CaMn} 0.775 \mathrm{Mg} 0.1 \mathrm{Ti} 0.125 \mathrm{O} 3-\delta$ oxygen carriers produced from different Mn and Ti sources Materials and Design, 89, 527-542.

JOHANSSON, M., MATTISSON, T., LYNGFELT, A. \& ABAD, A. 2008. Using continuous and pulse experiments to compare two promising nickel-based oxygen-carriers for use in chemical-looping technologies. Fuel, 87, 988-1001.

KASSMAN, H. 2012. Strategies to reduce gaseous KCl and chlorine in deposits during combustion of biomass in fluidized bed boilers. Ph.D Thesis, Chalmers University of Technology.

KELLER, M., FUNG, J., LEION, H. \& MATTISSON, T. 2016a. Cu-Impregnated Alumina/silica Bed Materials for Chemical Looping Reforming of Biomass Gasification Gas. Fuel, 180, 448-456.

KELLER, M., LEION, H. \& MATTISSON, T. 2016b. Chemical looping tar reforming using La/Sr/Fecontaining mixed oxides supported on ZrO2. Applied Catalysis B-Environmental, 183, 298-307.

KELLER, M., LEION, H., MATTISSON, T. \& THUNMAN, H. 2014. Investigation of Natural and Synthetic Bed Materials for Their Utilization in Chemical Looping Reforming for Tar Elimination in BiomassDerived Gasification Gas. Energy \& Fuels, 28, 3833-3840.

KOLBITSCH, P., BOLHAR-NORDENKAMPF, J., PRÖLL, T. \& HOFBAUER, H. 2009. Comparison of two Ni-based oxygen carriers for chemical looping combustion of natural gas in $140 \mathrm{~kW}$ continuous looping operation. Ind. Eng. Chem. Res, 48, 5542-5547.

KÄLlÉN, M., RYDÉN, M., DUESO, C., MATTISSON, T. \& LYNGFELT, A. 2013. CaMn0.9Mg0.1O3- $\delta$ as Oxygen Carrier in a Gas-Fired $10 \mathrm{kWth}$ Chemical-Looping Combustion Unit. Industrial \& Engineering Chemistry Research, 52, 6923-6932.

LARSSON, A., ISRAELSSON, M., LIND, F., SEEMANN, M. \& THUNMAN, H. 2014. Using ilmenite to reduce the tar yield in a dual fluidized bed gasification system. Energy and Fuels, 28, 2632-2644.

LEION, H., MATTISSON, T. \& LYNGFELT, A. 2007. The use of petroleum coke as fuel in chemical-looping combustion. Fuel, 86, 1947-1958.

LEWIS, W. K., GILLILAND, E. R. \& SWEENEY, M. P. 1951. Gasification of Carbon: Metal oxides in a fluidized powder bed. Chemical Engineering Progress, 47, 251-256.

LI, C. S. \& SUZUKI, K. 2009. Tar property, analysis, reforming mechanism and model for biomass gasification-An overview. Renewable \& Sustainable Energy Reviews, 13, 594-604.

LIND, F., BERGUERAND, N., SEEMANN, M. \& THUNMAN, H. 2013. Ilmenite and Nickel as Catalysts for Upgrading of Raw Gas Derived from Biomass Gasification. Energy \& Fuels, 27, 997-1007.

LIND, F., ISRAELSSON, M., SEEMANN, M. \& THUNMAN, H. 2012. Manganese oxide as catalyst for tar cleaning of biomass-derived gas. Biomass Convers. Biorefinery, 2, 133-140.

LIND, F., SEEMANN, M. \& THUNMANI, H. 2011. Continuous Catalytic Tar Reforming of Biomass Derived Raw Gas with Simultaneous Catalyst Regeneration. Industrial \& Engineering Chemistry Research, 50, 11553-11562.

LINDERHOLM, C., MATTISSON, T. \& LYNGFELT, A. 2009. Long-term integrity testing of spray-dried particles in a 10-kW chemical-looping combustor using natural gas as fuel Fuel, 88, 2083-2096. 
LINDERHOLM, C. \& SCHMITZ, M. 2016. Chemical-Looping Combustion of Solid Fuels in a 100 kW Dual Circulating Fluidized Bed System using Iron Ore as Oxygen Carrier. Journal of Environmental Chemical Engineering, 4, 1029-1039.

LINDERHOLM, C., SCHMITZ, M., BIERMANN, M., HANNING, M. \& LYNGFELT, A. 2017. Chemicallooping combustion of solid fuel in a $100 \mathrm{~kW}$ unit using sintered manganese ore as oxygen carrier. Submitted for publication.

LINDERHOLM, C., SCHMITZ, M., KNUTSSON, P. \& LYNGFELT, A. 2016. Chemical-looping combustion in a 100-kW unit using a mixture of ilmenite and manganese ore as oxygen carrier Fuel, 166, 533542.

LUO, S., ZENG, L. \& FAN, L. 2015. Chemical looping technology: Oxygen carrier characteristics. Annu. Rev. Chem. Biomol. Eng., 6, 53-75.

LYNGFELT, A. \& LECKNER, B. 2015. A 1000 MWth Boiler for Chemical-Looping Combustion of Solid Fuels - Discussion of Design and Costs. Applied Energy, 157, 475-487

LYNGFELT, A., LECKNER, B. \& MATTISSON, T. 2001. A fluidized-bed combustion process with inherent CO2 separation; application of chemical-looping combustion. Chem. Eng. Sci, 56, 3101-3113.

LYNGFELT, A. \& LINDERHOLM, C. Chemical-Looping Combustion of Solid Fuels - status and recent progress. 13th International Conference on Greenhouse Gas Control Technologies, GHGT-13, 2016 Lausanne, Switzerland.

LYNGFELT, A., MATTISSON, T., LINDERHOLM, C. \& RYDEN, M. 2016. Chemical-Looping Combustion of Solid Fuels - What is Needed to Reach Full-Scale ? . 4th Int. Conf. on Chemical Looping. Nanjing, China.

LYNGFELT, A. \& THUNMAN, H. 2005. Construction and $100 \mathrm{~h}$ of operational experience of a 10-kW chemical-looping combustor. Carbon Dioxide Capture for Storage in Deep Geologic Formations Results from the CO2 Capture Project, Volume 1 - Capture and Separation of Carbon Dioxide From Combustion Sources. London: Elsevier Science.

MARINKOVIC, J., BERGUERAND, N., LIND, F., SEEMANN, M. \& THUNMAN, H. 2015a. Using a Manganese Ore as Catalyst for Upgrading Biomass Derived Gas. Biomass Convers. Biorefinery, 5, 75-83.

MARINKOVIC, J., BERGUERAND, N., LIND, F., SEEMANN, M. \& THUNMAN, H. 2015b. Using a manganese ore as catalyst for upgrading biomass derived gas. Biomass Convers. Biorefinery, 5, 7583.

MARKSTRÖM, P., LINDERHOLM, C. \& LYNGFELT, A. 2013a. Analytical model of gas conversion in a $100 \mathrm{~kW}$ chemical-looping combustor for solid fuels-Comparison with operational results. Chem. Eng. Sci., 96, 131-141.

MARKSTRÖM, P., LINDERHOLM, C. \& LYNGFELT, A. 2013b. Chemical-looping combustion of solid fuels - Design and operation of a $100 \mathrm{~kW}$ unit with bituminous coal. Int. J. Greenhouse Gas Control, In press.

MARKSTRÖM, P., LYNGFELT, A. \& LINDERHOLM, C. 2012. Chemical-looping combustion in a $100 \mathrm{~kW}$ unit for solid fuels. 21 st International conference on fluidized bed combustion. Naples, Italy.

MATTISSON, T., ADÁNEZ, J., MAYER, K., SNIJKERS, F., WILLIAMS, G., WESKER, E., BERTSCH, O. \& LYNGFELT, A. 2014. Innovative oxygen carriers uplifting chemical-looping combustion. Energy Procedia, 63, 113-130.

MATTISSON, T., JING, D., LYNGFELT, A. \& RYDEN, M. 2016. Experimental investigation of binary and ternary combined manganese oxides for chemical-looping with oxygen uncoupling (CLOU). Fuel, 164, 228-236.

MATTISSON, T., LYNGFELT, A. \& LEION, H. 2009. Chemical-looping oxygen uncoupling for combustion of solid fuels International Journal of Greenhouse Gas Control, 3, 11-19.

MAYER, K., PENTHOR, S., PRÖLL, T. \& HOFBAUER, H. 2015. The different demands of oxygen carriers on the reactor system of a CLC plant - results of oxygen carrier testing in a $120 \mathrm{kWth}$ pilot plant. Applied Energy, 157, 323329.

MOLDENHAUER, P., RYDEN, M., MATTISSN, T., JAMAL, A. \& LYNGFELT, A. 2017. Chemicallooping combustion with heavy liquid fuels in a $10 \mathrm{~kW}$ pilot plant. Fuel Processing Technology, 156, 124-137.

MOLDENHAUER, P., RYDÉN, M., MATTISSON, T., HOTEIT, A., JAMAL, A. \& LYNGFELT, A. 2014. Chemical-looping combustion with fuel oil in a $10 \mathrm{~kW}$ pilot plant. Energy and Fuels, 28, 5978-5987.

ORTIZ, M., ABAD, A., DE DIEGO, L., GARCIA-LABIANO, F., GAYAN, P. \& ADANEZ, J. $2011 \mathrm{a}$. Optimization of hydrogen production by chemical-looping auto-thermal reforming working with $\mathrm{Ni}$ based oxygen-carriers. J. of Hydrogen Energy, 36, 9663-9672.

ORTIZ, M., GAYÁN, P., DE DIEGO, L., GARCÍA-LABIANO, F., ABAD, A., PANS, M. \& ADÁNEZ, J. 2011b. Hydrogen production with $\mathrm{CO} 2$ capture by coupling steam reforming of methane and chemical-looping combustion: Use of an iron-based waste product as oxygen carrier burning a PSA tail gas. J. of Power Sources, 196, 4370-4381. 
PANS, M., ABAD, A., DE DIEGO, L., GARCIA-LABIANO, F., GAYAN, P. \& ADANEZ, J. 2013. Optimization of $\mathrm{H} 2$ production with $\mathrm{CO} 2$ capture by steam reforming of methane integrated with a chemical-looping combustion system. J. of Hydrogen Energy, 38, 11878-11892.

PRÖLL, T., BOLHAR-NORDENKAMPF, J., KOLBITSCH, P. \& HOFBAUER, H. 2010. Syngas and a separate nitrogen/argon stream via chemical looping reforming - A $140 \mathrm{~kW}$ pilot plant study. Fuel, 89, 1249-1256.

RYDEN, M. 2008. Hydrogen production from fossil fuels with carbon dioxide capture, using chemical-looping technologies. Doctoral thesis, Chalmers University of Technology.

RYDEN, M., JING, D., KÄLLEN, M., LEION, H., LYNGFELT, A. \& MATTISSON, T. 2014. CuO-based oxygen-carrier particles for chemical-looping with oxygen uncoupling-Experiments in batch reactor and in continous operation. Ind. Eng. Chem. Res, 53, 6255-6267.

RYDEN, M. \& LYNGFELT, A. Hydrogen and power production with integrated carbon dioxide capture by chemical-looping reforming. 7th International Conference on Greenhouse Gas Control Technologies., 2004 Vancouver.

RYDÉN, M. \& LYNGFELT, A. 2006. Using steam reforming to produce hydrogen with carbon dioxide capture by chemical-looping reforming. Int. J. Hydrogen Energy, 31, 1271-1283.

RYDEN, M., LYNGFELT, A. \& MATTISSON, T. 2006. Synthesis gas generation by chemical-looping reforming in a continuously operating laboratory reactor. Fuel, 85, 1631-1641.

SHULMAN, A., CLEVERSTAM, E., MATTISSON, T. \& LYNGFELT, A. 2011 Chemical - Looping with oxygen uncoupling using $\mathrm{Mn} / \mathrm{Mg}$-based oxygen carriers - Oxygen release and reactivity with methane Fuel, 90, 941-950

STENBERG, V., RYDEN, M., MATTISSON, T. \& LYNGFELT, A. 2016. Hydrogen production by integration of steam reformation with chemical-looping combustion. 4th International conference on Chemical Looping. Nanjing, China.

THUNMAN, H., BREITHOLTZ, C., BERGUERAND, N. \& SEEMAN, M. 2013. Using an oxygen-carrier as bed material for combustion of biomass in a 12-MW circulating fludized-bed boiler. Fuel, 113, 300309.

TORRES, W., PANSARE, S. S. \& GOODWIN, J. G. 2007. Hot gas removal of tars, ammonia, and hydrogen sulfide from Biomass gasification gas. Catalysis Reviews-Science and Engineering, 49, 407-456.

VAN DER DRIFT, B. 2013. Chemicals from Biomass. IEA/Bioenergy-Task 33 Work.

VAN LITH, S., ALONSO-RAMIREZ, V., JENSEN, P., FRANDSEN, F. \& GLARBORG, P. 2006. Release to the gas phase of inorganic elements during wood combustion. Part I: Development and evaluation of quantification methods. Energy and Fuels, 20, 964-978.

ZAFAR, Q., MATTISSON, T. \& GEVERT, B. 2005. Integrated Hydrogen and Power Production with CO2 Capture Using Chemical-Looping Reforming - Redox Reactivity of Particles of $\mathrm{CuO}, \mathrm{Mn} 2 \mathrm{O} 3, \mathrm{NiO}$ and $\mathrm{Fe} 2 \mathrm{O} 3 \mathrm{Using} \mathrm{SiO} 2$ as a Support. Industrial and Engineering Chemistry Research, 44, 3485-3496.

ZHAO, D., SCHWEBEL, G., POUR, N., LEION, H., LIND, F. \& THUNMAN, H. Laboratory fluidized bed testing of ilmenite as bed material for oxygen carrier aided combustion (OCAC) 11th International conference on fluidized bed technology (CFB 2014), 2014 Bejing, China. 721-726. 